\title{
DECADAL CHANGES OF RADIOCARBON IN THE SURFACE BAY OF BENGAL: THREE DECADES AFTER GEOSECS AND ONE DECADE AFTER WOCE
}

\author{
Koushik Dutta ${ }^{1,2}$ • G V Ravi Prasad ${ }^{1,3} \cdot$ Dinesh K Ray $^{1}$ Sanjeev Raghav ${ }^{4}$ \\ ABSTRACT. Radiocarbon was measured in the surface seawater dissolved inorganic carbon (DIC) of the Bay of Bengal dur- \\ ing November 2006. A meridional transect of the $\Delta^{14} \mathrm{C}$ in DIC was obtained from measurements in closely spaced samples \\ collected roughly along $88^{\circ} \mathrm{E}$. The $\Delta^{14} \mathrm{C}$ of these samples ranged from $44 \%$ o to $57.7 \%$ (mean $51.8 \pm 1.1 \%$ o, $n=12$ ), and $38 \%$ o \\ at one station in the northern Bay of Bengal. The overall pattern of ${ }^{14} \mathrm{C}$ distribution in DIC of surface Bay of Bengal during \\ 2006 was roughly similar to that during the WOCE expedition of 1995 . These results indicate a $\Delta^{14} \mathrm{C}$ decline rate of $\sim 4 \%$ per \\ decade since WOCE in the surface Bay of Bengal, which is much smaller compared to a decline rate of 25\% per decade \\ observed in the 2 decades between the GEOSECS and WOCE expeditions, due to the smaller atmosphere-ocean $\Delta^{14} \mathrm{C}$ gradient.
}

\section{INTRODUCTION}

Temporal changes of radiocarbon in oceanic dissolved inorganic carbon (DIC) provide valuable clues for ocean circulation and air-sea $\mathrm{CO}_{2}$ exchange. Monitoring decadal changes of ${ }^{14} \mathrm{C}$ in oceanic DIC offers a way for validating ocean circulation models, which predict the spatial and temporal changes in the distribution of radiotracers (Guilderson et al. 2000). The earliest measurements of ${ }^{14} \mathrm{C}$ in the northern Indian Ocean were carried out during the GEOSECS expeditions of 1977-1978 (Stuiver and Östlund 1983), and in further detail 2 decades later during the WOCE expedition of 1994-1995 (Key and Quay 2002). Bhushan et al. (2000, 2003), Dutta et al. (2000, 2007), and Dutta (2001) reported DIC ${ }^{14} \mathrm{C}$ measurements at several other important locations in the northern Indian Ocean, from oceanographic cruises of the Physical Research Laboratory (PRL), India (Figure 1). Many of these stations were reoccupations of GEOSECS expeditions. Among other goals, these expeditions aimed to determine a "snapshot" scenario of oceanic ${ }^{14} \mathrm{C}$, ocean circulation tracers, and decadal changes in bomb- ${ }^{14} \mathrm{C}$ penetration.

The Bay of Bengal in the northern Indian Ocean experiences high rainfall and seasonally reversing surface ocean circulation driven by monsoonal winds (Schott and McCreary 2001; Shankar et al. 2002). The basin receives large freshwater input through several major rivers, as well as the Indonesian Throughflow (Sengupta et al. 2006). The northern Bay of Bengal also receives a large amount of freshwater through submarine groundwater discharge (Moore 1997). Owing to this unique oceanographic setting, with mixing of various water masses with contrasting ${ }^{14} \mathrm{C}$ contents and seasonally reversing circulation, the Bay of Bengal region is an area of considerable interest for studies of ${ }^{14} \mathrm{C}$ as a tracer. The WOCE surface $\Delta^{14} \mathrm{C}$ results show large meridional variation (51-78\%o along $90^{\circ} \mathrm{E}$ ) and much smaller zonal variation (55-65\%o along $10^{\circ} \mathrm{N}$ ). These measurements revealed the highest surface $\Delta^{14} \mathrm{C}$ values, around 78\%o, observed in the SE Bay of Bengal near $8^{\circ} 30^{\prime} \mathrm{N}$ close to the Indonesian Throughflow, and 64\% at a station in the NE Bay of Bengal. The lowest surface $\Delta^{14} \mathrm{C}$ values of $~ 52 \%$ were observed in the SW Bay of Bengal due to advection of ${ }^{14} \mathrm{C}$-depleted waters from the Arabian Sea. Low $\Delta^{14} \mathrm{C}$ values are also expected in the northern Bay of Bengal close to the GangesBrahmaputra estuary, due to submarine discharge of old groundwater. ${ }^{14} \mathrm{C}$ ages of coastal groundwater samples near the northern Bay of Bengal range from $\sim 3 \mathrm{kyr}$ BP to as old as $\sim 9 \mathrm{kyr}$ BP (Ravi

\footnotetext{
${ }^{1}$ Institute of Physics, Sachivalaya Marg, Bhubaneswar 751 005, India.

${ }^{2}$ Present address: Large Lakes Observatory, University of Minnesota-Duluth, Duluth, Minnesota 55812, USA. Corresponding author. Email: kdutta@d.umn.edu.

${ }^{3}$ Center for Applied Isotope Studies, University of Georgia, Athens, Georgia 30602, USA.

${ }^{4}$ Marine Wing, Geological Survey of India, Kolkata 700 091, India.
}

(C) 2010 by the Arizona Board of Regents on behalf of the University of Arizona Proceedings of the 20th International Radiocarbon Conference, edited by A J T Jull RADIOCARBON, Vol 52, Nr 2-3, 2010, p 1191-1196 


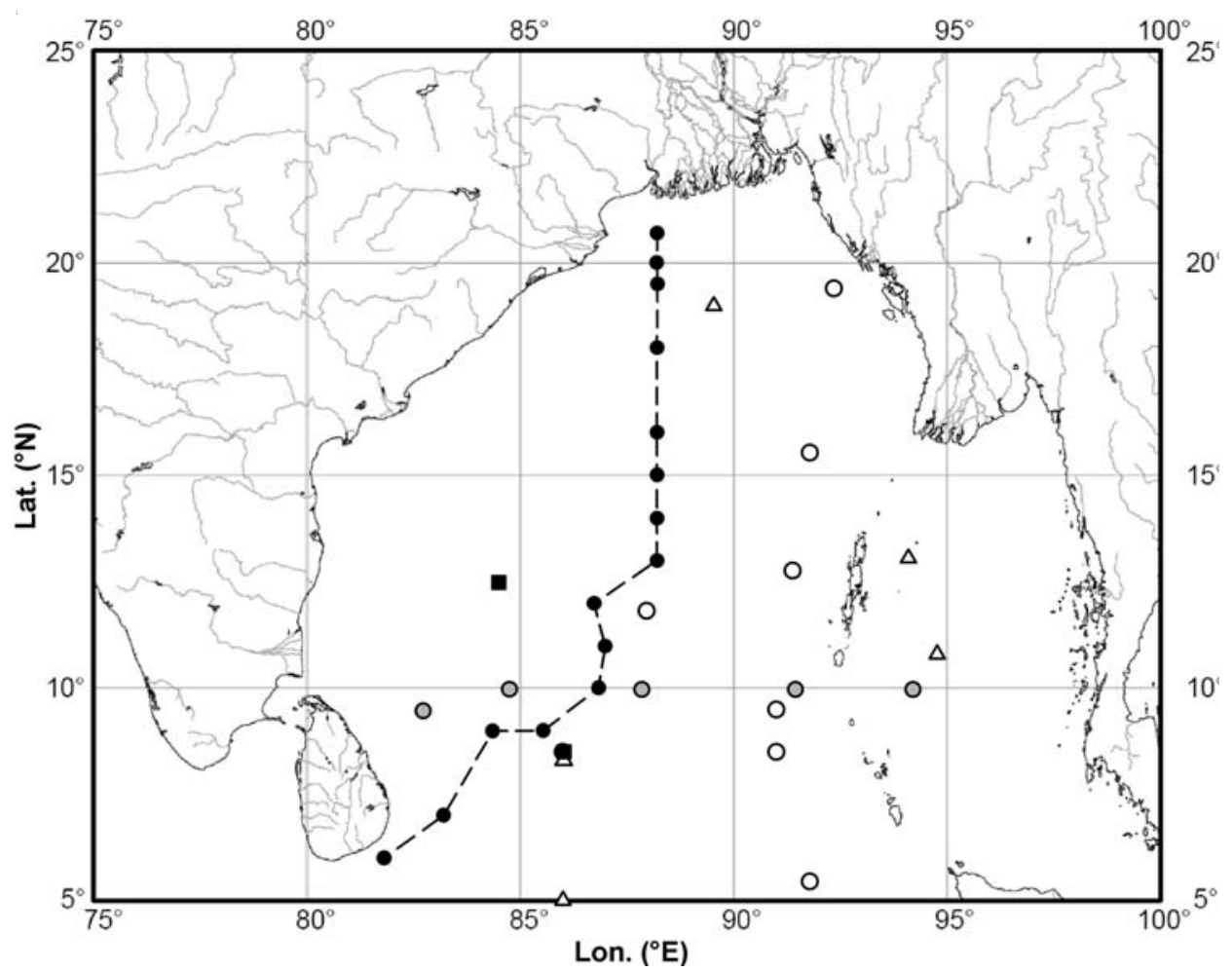

Figure $1{ }^{14} \mathrm{C}$ sampling stations in the Bay of Bengal: GEOSECS (stations \#445 and \#446, squares); WOCE (I09N, open circles; I10E, shaded circles); PRL (triangles); SM-TT-06 cruise (filled circles).

Prasad et al. 2008). Mixing of old groundwater via submarine groundwater discharge can significantly influence marine DIC ${ }^{14} \mathrm{C}$ ages. Measurements of samples from a PRL expedition in 1999 recorded the lowest surface $\Delta^{14} \mathrm{C}$ of $18 \pm 6 \%$ near $20^{\circ} \mathrm{N}$ (Dutta et al. 2000; Dutta 2001).

To understand the spatial variation and decadal change of ${ }^{14} \mathrm{C}$ in the surface water DIC of Bay of Bengal, we planned to measure ${ }^{14} \mathrm{C}$ in surface seawater samples at close by locations. Here, we report $\Delta^{14} \mathrm{C}$ measured in the DIC of surface Bay of Bengal, measured in samples collected in 2006 along a meridional transect.

\section{MATERIALS AND METHODS}

Surface seawater samples were collected onboard the R/V Samudra Manthan during November 2006, approximately following a meridional transect along $88^{\circ} \mathrm{E}$ in the central Bay of Bengal from $21^{\circ} \mathrm{N}$ to about $5^{\circ} \mathrm{N}$ (Figure 1). Samples were collected from a depth of $5 \mathrm{~m}$ using 5-L PVC Niskin water samplers. Soon after collection, the samples were poisoned with saturated aqueous $\mathrm{HgCl}_{2}$ solution and stored in refrigerated airtight bottles until further analysis. Salinity (conductivity) and temperature were measured onboard using a Multiline $\mathrm{P} 4^{\mathrm{TM}}$ water analysis kit. The samples were processed at the ${ }^{14} \mathrm{C}$ laboratory of the Institute of Physics, India. $\mathrm{CO}_{2}$ was extracted from these samples by acidifying with $\mathrm{H}_{3} \mathrm{PO}_{4}$ under vacuum. The liberated $\mathrm{CO}_{2}$ was cryogenically purified, converted to graphite by $\mathrm{H}_{2}$ reduction over Fe catalyst (Vogel et al. 1984), and pressed into targets for accelerator mass spectrometry (AMS) ${ }^{14} \mathrm{C}$ analysis. ${ }^{14} \mathrm{C}$ measurements in the graphite samples were carried out at the AMS facility of the Center for Applied Isotope Studies, University of Georgia, 
Athens, USA, using a NEC 1.5 SDH-1 0.5MV compact AMS system. An aliquot of $\mathrm{CO}_{2}$ was used for $\delta^{13} \mathrm{C}$ analysis at the National Institute of Oceanography, Goa, India, using a Finnigan Delta $V^{\mathrm{TM}}$ stable isotope mass spectrometer. The average precision of $\delta^{13} \mathrm{C}$ measurements was $0.04 \%$. The measured $\delta^{13} \mathrm{C}$ values in these samples ranged from -0.4 to $-1.2 \%$ (Table 1 ). These values possibly indicate a fractionation of about $-2 \%$, since $\delta^{13} \mathrm{C}$ of surface ocean DIC typically range from $\sim 1$ to $2 \%$. During the $\mathrm{CO}_{2}$ extraction by acid-hydrolysis, even though the samples were agitated under vacuum using an ultrasonic bath, they were not actively purged using a stream of inert gas. The observed fractionation is likely due to incomplete $\mathrm{CO}_{2}$ extraction during the hydrolysis stage. However, in all cases the $\mathrm{CO}_{2}$ yields were $>95 \%$ of the expected amount. The $\delta^{13} \mathrm{C}$ results were only used for isotopic fractionation correction to determine $\Delta^{14} \mathrm{C}$ (Stuiver and Polach 1977). Typical internal precisions for AMS $\Delta^{14} \mathrm{C}$ measurements were better than $\pm 3 \%$, while the repeat measurements were within $\pm 6 \% .{ }^{14} \mathrm{C}$ measurements in the modern standards VIRI-A and VIRI-C agreed very well with their consensus values. The precision of $\Delta^{14} \mathrm{C}$ measurements in the modern standards was $\pm 5 \%$.

Table 1 Results of ${ }^{14} \mathrm{C}$ analysis in surface samples from the Bay of Bengal.

\begin{tabular}{llllllll} 
Sample & Date & $\begin{array}{l}\text { Lat. }\left({ }^{\circ} \mathrm{N}\right) ; \\
\text { Lon. }\left({ }^{\circ} \mathrm{E}\right)\end{array}$ & $\begin{array}{l}\text { Temp. } \\
\left({ }^{\circ} \mathrm{C}\right)\end{array}$ & $\begin{array}{l}\text { Salinity } \\
(\mathrm{mg} / \mathrm{L})\end{array}$ & $\begin{array}{l}\delta^{13} \mathrm{C} \\
(\%)\end{array}$ & $\begin{array}{l}\Delta^{14} \mathrm{C} \\
(\%)\end{array}$ & $\begin{array}{l}\text { Lab } \\
\text { code }\end{array}$ \\
\hline SM-TT-06 / W-9 & 12-Nov-06 & $20.69 ; 88.21$ & 28.4 & 30.0 & -1.23 & - & - \\
SM-TT-06 / W-10 & 13-Nov-06 & $20.00 ; 88.20$ & 28.4 & 32.0 & -0.59 & $38.5 \pm 2.4$ & IP-869 \\
SM-TT-06 / W-11 & 13-Nov-06 & $19.50 ; 88.22$ & 28.2 & 30.8 & -0.68 & $52.8 \pm 2.9$ & IP-870 \\
SM-TT-06 / W-12 & 14-Nov-06 & $18.00 ; 88.21$ & 28.1 & 30.2 & -0.52 & $55.3 \pm 2.4$ & IP-871 \\
SM-TT-06 / W-13 & 14-Nov-06 & $17.00 ; 88.21$ & 28.5 & 29.7 & -0.71 & - & - \\
SM-TT-06 / W-14 & 14-Nov-06 & $16.01 ; 88.21$ & 29.1 & 32.4 & -0.39 & $51.4 \pm 2.5$ & IP-872 \\
SM-TT-06 / W-15 & 15-Nov-06 & $15.00 ; 88.21$ & 29.3 & 32.2 & -0.49 & $49.5 \pm 2.4$ & IP-873 \\
SM-TT-06 / W-16 & 15-Nov-06 & $14.00 ; 88.21$ & 29.3 & 31.8 & -0.61 & $57.7 \pm 2.7$ & IP-874 \\
SM-TT-06 / W-17 & 16-Nov-06 & $13.01 ; 88.21$ & 29.3 & 32.3 & -0.41 & $44.0 \pm 2.4$ & IP-875 \\
SM-TT-06 / W-18 & 16-Nov-06 & $12.00 ; 86.74$ & 29.2 & 32.0 & -0.88 & - & - \\
SM-TT-06 / W-19 & 17-Nov-06 & $10.99 ; 86.99$ & 29.2 & 32.8 & -0.43 & $50.2 \pm 2.8$ & IP-878 \\
SM-TT-06 / W-20 & 17-Nov-06 & $10.01 ; 86.84$ & 29.7 & 33.2 & -0.61 & $52.2 \pm 2.7$ & IP-879 \\
SM-TT-06 / W-21 & 18-Nov-06 & $9.00 ; 85.54$ & 29.8 & 32.4 & -0.86 & $55.9 \pm 3.4$ & IP-880 \\
SM-TT-06 / W-22 & 18-Nov-06 & $8.99 ; 84.36$ & 29.1 & 32.0 & -0.83 & $54.4 \pm 3.0$ & IP-882 \\
SM-TT-06 / W-23 & 19-Nov-06 & $7.01 ; 83.21$ & 29.2 & 32.3 & -0.62 & $52.7 \pm 2.8$ & IP-884 \\
SM-TT-06 / W-24 & 19-Nov-06 & $6.00 ; 81.82$ & 29.3 & 29.3 & -0.99 & $49.2 \pm 2.7$ & IP-885 \\
\hline
\end{tabular}

\section{RESULTS AND DISCUSSION}

\section{Spatial Variation of Surface $\Delta^{14} \mathrm{C}$}

The DIC $\Delta^{14} \mathrm{C}$ of these surface seawater samples are presented in Table 1 and Figure 2. For the stations SM-TT-06/W- 11 to $\mathrm{W}-24$, the $\Delta^{14} \mathrm{C}$ values mostly range from $44 \%$ o to $57.7 \%$ (error-weighted mean $51.8 \pm 1.1 \%$, $n=12$ ). As evident in Figure 2, the overall pattern of $\Delta^{14} \mathrm{C}$ distribution was roughly similar as it was during the WOCE expedition a decade ago. Higher $\Delta^{14} \mathrm{C}$ values of $56 \%$ were recorded in the southern Bay of Bengal near $9^{\circ} \mathrm{N}$, and also around $19^{\circ} \mathrm{N}$. The lowest $\Delta^{14} \mathrm{C}$ of $38.5 \%$ o was observed at the station SM-TT-06/W-10 in the northern Bay of Bengal at $20^{\circ} \mathrm{N}$. A low $\Delta^{14} \mathrm{C}$ of $44 \%$ was also measured at SM-TT-06/W-17 in the central Bay of Bengal around $13^{\circ} \mathrm{N}$. 


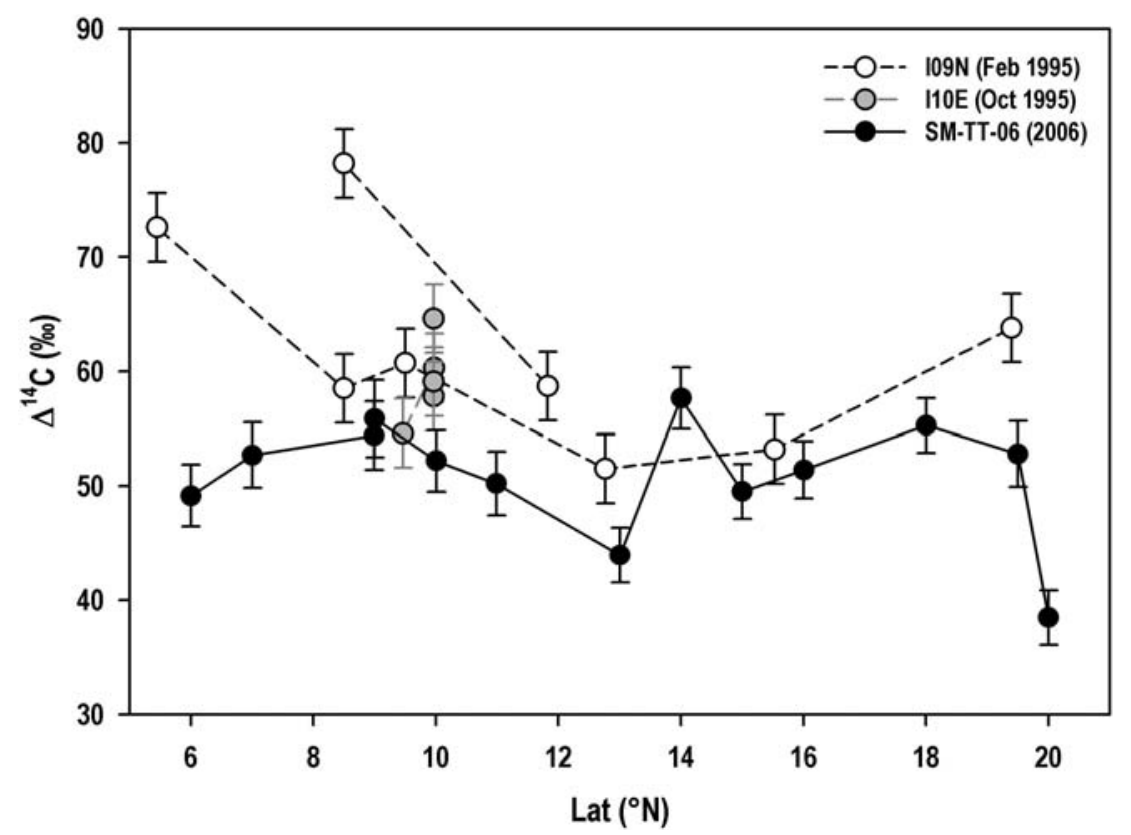

Figure 2 Spatial variation of $\Delta^{14} \mathrm{C}$ in the DIC of the surface Bay of Bengal during the WOCE expedition and this study.

\section{Decadal Changes of Surface $\Delta^{14} \mathrm{C}$}

To determine decadal changes in surface $\Delta^{14} \mathrm{C}$, we focus on the ${ }^{14} \mathrm{C}$ measurements in the southwestern Bay of Bengal (within $7-13^{\circ} \mathrm{N}$ and $82-88^{\circ} \mathrm{E}$ ), where ${ }^{14} \mathrm{C}$ data are available from all 3 earlier expeditions. Two GEOSECS stations, 4 WOCE stations (2 each of I09N and I10E), 1 PRL station, and 4 stations from this study (IOP/GSI) were chosen to determine their error-weighted average $\Delta^{14} \mathrm{C}$ values. The average surface water $\Delta^{14} \mathrm{C}$ during early 1978 was $110 \pm 10 \%$ for GEOSECS stations \#445 and \#446. The average $\Delta^{14} \mathrm{C}$ for WOCE I09N station (February 1995) was $67 \pm 10 \%$, and $58 \pm 3 \%$ for WOCE I10N station (October 1995). PRL ${ }^{14} \mathrm{C}$ measurements at the station SS\#1523829 (reoccupation of GEOSECS \#446) were $38 \pm 7 \%$ at $5 \mathrm{~m}$ and $64 \pm 4 \%$ at $45 \mathrm{~m}$. The average $\Delta^{14} \mathrm{C}$ for the 4 stations of this study (SM-TT-06/W17 to W21) was $53.2 \pm 2.5 \%$. These decadal changes of surface $\Delta^{14} \mathrm{C}$ in the southwestern Bay of Bengal are shown in Figure 3. This analysis shows that $\Delta^{14} \mathrm{C}$ in the surface Bay of Bengal DIC has decreased at 25\% per decade between 1978 and 1995, but only 4\%o in the decade between 1995 and 2006. A lower decline rate of surface ocean $\Delta{ }^{14} \mathrm{C}$ during the last decade is expected given the significantly lower atmosphere-ocean ${ }^{14} \mathrm{C}$ gradient. Tropospheric $\Delta^{14} \mathrm{C}$ in the Northern Hemisphere has changed from 326\% in 1978 (Hua and Barbetti 2004) to 105\% in 1995 (Dutta et al. 2006) and 52\%o during February 2007 (Xu et al. 2007). The atmosphere-ocean ${ }^{14} \mathrm{C}$ gradient at the Bay of Bengal was thus negligible during the period of this study.

\section{Seasonal Changes of Surface $\Delta^{14} \mathrm{C}$}

In the above analysis of decadal ${ }^{14} \mathrm{C}$ changes, we have ignored any effect of seasonal ${ }^{14} \mathrm{C}$ variations in the surface Bay of Bengal. A large seasonal ${ }^{14} \mathrm{C}$ variation is not unexpected given the strong seasonality of monsoon-driven surface currents. To date, there is no detailed study of seasonal $\Delta^{14} \mathrm{C}$ changes in the Bay of Bengal. From one-time ${ }^{14} \mathrm{C}$ measurements, it is not possible to study such sea- 


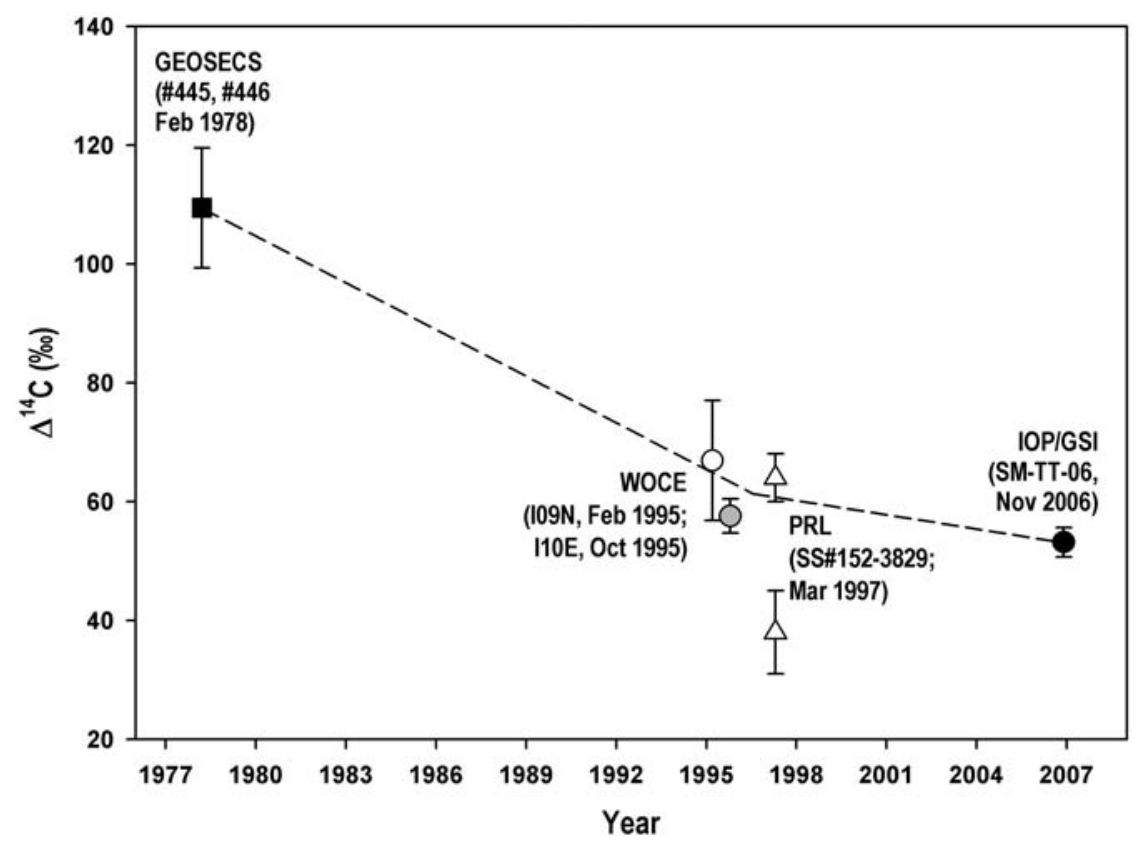

Figure 3 Decadal $\Delta^{14} \mathrm{C}$ changes in the DIC of the surface Bay of Bengal (near $10^{\circ} \mathrm{N}, 86^{\circ} \mathrm{E}$ )

sonal changes. The results from WOCE stations I09N (February 1995) and I10E (October 1995) indicate a seasonal $\Delta^{14} \mathrm{C}$ shift in the southwestern Bay of Bengal by $10 \%$, which is not statistically significant. Average surface $\Delta^{14} \mathrm{C}$ values measured during the PRL expeditions in February/March of 1997 and 1999 was 47\%o. From these results, it is apparent that the spatiotemporal variation of surface $\Delta^{14} \mathrm{C}$ in the Bay of Bengal is complex. A large variability in $\Delta^{14} \mathrm{C}$ of surface ocean DIC is not uncommon. Druffel and Griffin (2008) have demonstrated daily variability between $11 \%$ and $30 \%$ in surface DIC $\Delta^{14} \mathrm{C}$ at multiple occupations of single sites in the central North Pacific, the Sargasso Sea, and the Southern Ocean. Monthly seasonal $\Delta^{14} \mathrm{C}$ amplitudes were $\sim 10-20 \%$ observed in the subtropical Pacific (Druffel 1987). Surprisingly, the amplitudes of such variations were not necessarily lower during the late 1990s than they were in the 1980s.

Further measurements are needed to better understand the spatial and temporal changes in $\Delta^{14} \mathrm{C}$ of the surface Bay of Bengal. Measurements of $\Delta^{14} \mathrm{C}$ along multiple transects are essential. Monthly measurements of $\Delta^{14} \mathrm{C}$ at selected coastal locations are needed to decipher seasonal changes of ${ }^{14} \mathrm{C}$ in DIC in response to seasonally reversing surface circulation. A detailed study of $\Delta^{14} \mathrm{C}$ close to the Ganges-Brahmaputra estuary in the northern Bay of Bengal may give insights to the effects of submarine groundwater discharge on marine ${ }^{14} \mathrm{C}$.

\section{CONCLUSIONS}

$\Delta^{14} \mathrm{C}$ in the DIC of the surface Bay of Bengal during 2006 mostly ranged from 44\% to 58\%o (mean $52 \pm 1 \%$ ). The lowest $\Delta^{14} \mathrm{C}$ value of $38 \%$ was observed at a station in the northern Bay of Bengal. The latitudinal $\Delta^{14} \mathrm{C}$ pattern as observed during November 2006 roughly followed the overall trend observed during the WOCE expedition during February and October 1995. The change in surface $\Delta^{14} \mathrm{C}$ as observed for the southwestern Bay of Bengal (near $10^{\circ} \mathrm{N}, 86^{\circ} \mathrm{E}$ ) was much smaller during 1995-2006 than it was in the 2 decades previous. The atmosphere-ocean $\Delta^{14} \mathrm{C}$ gradient for the Bay 
of Bengal during late 2006 was negligible. Further measurements are needed to evaluate the effects of seasonal circulation changes and submarine groundwater discharge on the ${ }^{14} \mathrm{C}$ in DIC at the northern Bay of Bengal.

\section{ACKNOWLEDGMENTS}

The authors would like to thank the captain, crews, and staffs of the R/V Samudra Manthan for logistics support, and R Agnihotri for the $\delta^{13} \mathrm{C}$ measurements at National Institute of Oceanography. Financial support for this study was obtained from the Department of Atomic Energy and Ministry of Earth Sciences, Government of India.

\section{REFERENCES}

Bhushan R, Somayajulu BLK, Chakraborty S, Krishnaswami S. 2000. Radiocarbon in the Arabian Sea water column: temporal variations in bomb ${ }^{14} \mathrm{C}$ inventory since the GEOSECS and $\mathrm{CO}_{2}$ air-sea exchange rates. Journal of Geophysical Research 105(C6):14,273-82.

Bhushan R, Dutta K, Mulsow S, Povinec PP, Somayajulu BLK. 2003. Distribution of natural and man-made radionuclides during the reoccupation of GEOSECS stations 413 and 416 in the Arabian Sea: temporal changes. Deep-Sea Research II 50(17-21):2777-84.

Druffel ERM. 1987. Bomb radiocarbon in the Pacific: annual and seasonal timescale variations. Journal of Geophysical Research 45(3):667-98.

Druffel ERM, Griffin S. 2008. Daily variability of dissolved inorganic radiocarbon at three sites in the surface ocean. Marine Chemistry 110(3-4):185-9.

Dutta K. 2001. Study of marine processes in the northern Indian Ocean using radiocarbon [PhD dissertation]. M.S. University of Baroda, Vadodara, India. 142 p.

Dutta K, Bhushan R, Somayajulu BLK. 2000. Anthropogenic radiocarbon in Bay of Bengal: two decades after GEOSECS [abstract]. 17th International Radiocarbon Conference, 18-23 June 2000, Judean Hills, Israel.

Dutta K, Bhushan R, Somayajulu BLK, Rastogi N. 2006. Inter-annual variation in atmospheric $\Delta^{14} \mathrm{C}$ over the northern Indian Ocean. Atmospheric Environment 40(24):4501-12.

Dutta K, Bhushan R, Somayajulu BLK. 2007. Rapid vertical mixing rates in the deep waters of the Andaman Basin. Science of the Total Environment 384(1-3): 401-8.

Guilderson TP, Caldeira K, Duffy PB. 2000. Radiocarbon as a diagnostic tracer in ocean and carbon cycle modeling. Global Biogeochemical Cycles 14(3):887902.

Hua Q, Barbetti M. 2004. Review of tropospheric bomb ${ }^{14} \mathrm{C}$ data for carbon cycle modeling and age calibration purposes. Radiocarbon 46(3):1273-98.
Key RM, Quay PD. 2002. US WOCE Indian Ocean Survey: final report for radiocarbon. Ocean Tracer Laboratory, Technical Report 02-1.

Moore WS. 1997. High fluxes of radium and barium from the mouth of the Ganges-Brahmaputra River during low river discharge suggest a large groundwater source. Earth and Planetary Science Letters 150(1-2):141-50.

Ravi Prasad GV, Dutta K, Ray DK. 2008. Radiocarbon AMS at IOP: system improvements and dating of groundwater from Bhadrak district, Orissa. Nuclear Instruments and Methods in Physics Research B 266(8):1833-6.

Sengupta D, Bharat Raj GN, Shenoi SSC. 2006. Surface freshwater from Bay of Bengal runoff and Indonesian Throughflow in the tropical Indian Ocean. Geophysical Research Letters 33: L22609, doi:10.1029/ 2006 GL027573.

Schott FA, McCreary Jr JP. 2001. The monsoon circulation of the Indian Ocean. Progress in Oceanography 51(1):1-123.

Shankar D, Vinayachandran PN, Unnikrishnan AS. 2002. The monsoon currents in the north Indian Ocean. Progress in Oceanography 52(1):63-120.

Stuiver M, Östlund HG. 1983. GEOSECS Indian Ocean and Mediterranean radiocarbon. Radiocarbon 25(1): 1-29.

Stuiver M, Polach HA. 1977. Discussion: reporting of ${ }^{14} \mathrm{C}$ data. Radiocarbon 19(3):355-63.

Vogel JS, Southon JR, Nelson DE, Brown TA. 1984. Performance of catalytically condensed carbon for use in accelerator mass spectrometry. Nuclear Instruments and Methods in Physics Research B 5(2):289-93.

Xu X, Trumbore S, Ajie H, Tyler S. 2007. $\Delta^{14} \mathrm{C}$ of atmospheric $\mathrm{CO}_{2}$ over the Subtropical and Equatorial Pacific and at Point Barrow, Alaska. EOS Transactions AGU 88(52), Fall Meeting Supplement, Abstract B43D-1581. 